УДК 343.59 (477)

DOI https://doi.org/10.32849/2663-5313/2020.5.38

Вікторія Базелюк,

канд. юрид.наук,

асистент кафедри кримінального права

Начіонального юридичного університету імені Ярослава Мудрого

Свгенія Коваленко,

студентка III курсу

Інституту підготовки кадрів для органів юстииї Украӥни

Начіонального юридичного університету імені Ярослава Мудрого

\title{
ВІДМЕЖУВАННЯ НЕЗАКОННОГО ПРОВЕДЕННЯ ПОШУКОВИХ РОБІТ НА ОБ'ЄКТІ АРХЕОЛОГІЧНОЇ СПАДЩИНИ, ЗНИЩЕННЯ, РУЙНУВАННЯ АБО ПОШКОДЖЕННЯ ОБ’ЄКТІВ КУЛЬТУРНОЇ СПАДЩИНИ ВІД СУМІЖНИХ СКЛАДІВ ЗЛОЧИНІВ
}

Статтю присвячено питанням відмежування незаконного проведення пошукових робіт на об'єкті археологічної спадшини, знищення, руйнування або пошкодження об'єктів культурної спадщини (ст. 298 КК) від суміжних складів злочинів.

Закон про кримінальну відповідальність містить ряд злочинів, які можуть бути віднесені до суміжних зі злочином, передбаченим ст. 298 КК. При ивому співвідношення суміжних складів злочинів слід відрізняти від конкурениії загальної та спеціальної норми. Суміжні склади злочинів мають багато спільних ознак, окрім, як правило, однієї, яка іє розмежувальною. Враховуючи спечифіку незаконного проведення археологічних розвідок, розкопок, інших земляних чи підводних робіт на об'єкті археологічної спадщини, знищення, руйнування або пошкодження об'єктів культурної спадщини, слід зазначити, що більшість із суміжних із даним злочином діянь відрізняються від нього за предметом злочину, змістом суб'єктивної сторони, а також деякими особливостями об'єктивної сторони. До суміжних зі злочином, передбаченим ст. 298 КК, слід віднести: пошкодження релігійних споруд чи культових будинків (ст. 178 КК), незаконне утримування, осквернення або знищення релігійних святинь (ст. 179 КК), незаконне привласнення особою знайденого або чужого майна, що випадково опинилося у неї ( cm. 193 КК), умисне знищення або пошкодження територій, взятих під охорону держави, та об'єктів природно-заповідного фонду (ст. 252 КК), наругу над могилою, іншим місием поховання або над тілом померлого (ст. 297 КК) та наругу над державними символами (ст. 338 КК).

Актуальність та важливість даної статті полягає в тому, що на практиці досить часто виникає питання, за якими ознаками слід відмежовувати незаконне проведення пошукових робіт на об'єкті археологічної спадщини, знищення, руйнування або пошкодження об'єктів культурної спадщини від указаних вище суміжних складів злочинів та в яких випадках досліджуваний злочин слід кваліфікувати за сукупністю з перерахованими злочинними діяннями.

Ключові слова: археологічні розвідки, археологічні розкопки, наруга над могилою, культурні цінності, релігійні святині, об'єкт природно-заповідного фонду.

Постановка проблеми. Питання відмежування суміжних складів злочинів є досить актуальним не лише для науки кримінального права, а й для практики застосування закону про кримінальну відповідальність. Шодо окремих складів злочинів зазначена проблема більш-менш вирішена у відповідних постановах Пленуму Верховного Суду
України. Хоча іноді правова оцінка суспільно небезпечного діяння Верховним Судом України не завжди є прикладом правильного застосування норм кримінального закону. Що стосується питання відмежування посягань на об'єкти культурної та археологічної спадщини від суміжних складів злочинів, то натепер воно не знайшло свого вирішення 
ні в постановах чи рішеннях вищої судової інстанції, ні в теорії кримінального права.

Аналіз останніх досліджень та публікацій. Окремі проблемні питання посягань на об'єкти культурної та археологічної спадщини розглядалися в роботах таких учених, як В. І. Акуленко, Р. В. Асейкін, Є. П. Гайворонський, Т. Г. Каткова, В. В. Кузнецов, Є. І. Кузьменко, Т. В. Курило, Л. А. Литовченко, В. А. Ломако, П. С. Матишевський, О. С. Мільчуцька, М. С. Міщенко, В. О. Навроцький, Б. М. Одайник, І. Г. Поплавський, О. С. Сотула, О. В. Усенко та ін. Але, незважаючи на чималу кількість наукових розробок стосовно посягань на культурні цінності, проблема відмежування суміжних злочинів даної сфери наразі не знайшла остаточного свого вирішення

Мета статті - виявити злочини, які $€$ суміжними 3 незаконним проведенням пошукових робіт на об'єкті археологічної спадщини, знищенням, руйнуванням або пошкодженням об'єктів культурної спадщини, та провести їх відмежування

Виклад основного матеріалу. Закон про кримінальну відповідальність містить ряд злочинів, які можуть бути віднесені до суміжних зі злочином, передбаченим ст. 298 КК. Співвідношення суміжних складів злочинів слід відрізняти від конкуренції загальної та спеціальної норми. Суміжні склади злочинів мають багато спільних ознак, окрім, як правило, однієї, яка і є розмежувальною. Враховуючи специфіку незаконного проведення пошукових робіт на об'єкті археологічної спадщини, знищення, руйнування або пошкодження об'єктів культурної спадщини, зазначимо, що більшість із суміжних із даним злочином діянь відрізняються від нього за предметом злочину, змістом суб'єктивної сторони, а також деякими особливостями об'єктивної сторони. До суміжних зі злочином, передбаченим ст. 298 КК, слід віднести: пошкодження релігійних споруд чи культових будинків (ст. 178 КК), незаконне утримування, осквернення або знищення релігійних святинь (ст. 179 КК), незаконне привласнення особою знайденого або чужого майна, що випадково опинилося у неї ( ст. 193 КК), умисне знищення або пошкодження територій, взятих під охорону держави, та об'єктів природно-заповідного фонду (ст. 252 КК), наругу над могилою, іншим місцем поховання або над тілом померлого (ст. 297 КК) та наругу над державними символами (ст. 338 КК).

У зв’язку з цим на практиці досить часто виникає питання, за якими ознаками слід відмежовувати незаконне проведення пошуко- вих робіт на об’єкті археологічної спадщини, знищення, руйнування або пошкодження об'єктів культурної спадщини від указаних вище суміжних складів злочинів та в яких випадках досліджуваний злочин слід кваліфікувати за сукупністю з перерахованими злочинними діяннями.

Відмежування знищення, руйнування або пошкодження об’єктів культурної спадщини від пошкодження релігійних споруд чи культових будинків (ст. 178 КК) може бути проведено на основі характеристики родового та безпосереднього об'єктів даних злочинів. Знищення, руйнування або пошкодження об'єктів культурної спадщини є злочином проти громадського порядку та моральності, які і є його родовим об'єктом. Безпосереднім же об'єктом даного злочину виступають суспільні відносини, які забезпечують цілісність та недоторканість об’єктів культурної та археологічної спадщини, що впливають на формування основних принципів морального (духовного) життя суспільства, шкода яким заподіюється шляхом порушення встановлених законом правил поводження iз зазначеними предметами. Пошкодження релігійних споруд чи культових будинків $€$ злочином проти конституційних прав і свобод людини і громадянина і безпосередньо спричиняє шкоду праву людини на свободу віросповідання, яке включає свободу сповідувати будь-яку релігію, безперешкодно відправляти одноособово чи колегіально релігійні культи і ритуальні обряди, вести релігійну діяльність, у т.ч. з використанням релігійних споруд чи культових будинків [1, с. 12]. Окрім того, предметом злочину, передбаченого ст. 298 КК, є об'єкти культурної спадщини місцевого та національного значення, а предметом злочину, передбаченого ст. 178 КК, є релігійні споруди або культові будинки. Але на практиці трапляються випадки, коли релігійні споруди чи культові будинки мають особливу історичну чи культурну цінність і віднесені до об'єктів культурної спадщини місцевого чи національного значення та занесені до Державного реєстру нерухомих пам'яток України. Таким прикладом є собор Святого Юра у Львові, який одночасно є і релігійною спорудою, і об'єктом культурної спадщини національного значення. У такому випадку дії винної особи слід кваліфікувати за сукупністю злочинів за ст. 178 та ст. 298 КК. Слід зазначити, що відмінність об'єктивної сторони даних злочинів полягає лише в тому, що ст. 178 КК не передбачає такий вид діяння, як знищення.

Схожа ситуація спостерігається і у розмежуванні знищення, руйнування або пошкодження об'єктів культурної спадщини 
та незаконного утримування, осквернення або знищення релігійних святинь (ст. 179 КК). Основна відмінність між цими злочинами полягає в об'єкті. Злочин, передбачений ст. 179 КК, має такий самий родовий об’єкт, як і злочин, передбачений ст. 178 КК. Безпосереднім об'єктом злочину, передбаченого ст. 179 КК, є суспільні відносини, що забезпечують свободу віросповідання і повагу почуттів віруючих [2, с. 142]. Окрім того, предметом злочину, передбаченого ст. 179 КК, є релігійні святині, які можуть водночас бути об'єктами культурної спадщини місцевого чи національного значення та бути занесеними до Державного реєстру нерухомих пам'яток України. У такому випадку іх знищення потребує додаткової кваліфікації за відповідною частиною ст. 298 КК. В об'єктивній стороні досліджуваних злочинів спостерігається лише частковий збіг діянь. Спільним для обох злочинів $€$ поняття знищення, а утримування притаманне лише ст. 179 КК, руйнування - лише ст. 298 КК. Що стосується поняття осквернення, то, як правильно зазначає Б. М. Одайник, за певних умов воно може трактуватися і як пошкодження у складі злочину, передбаченого ст. 298 КК [1, с. 12].

Подібність злочинів, передбачених ст. 193 КК та ч. 2 ст. 298 КК, полягає у схожості їх предметів, а саме такої притаманної їм ознаки, як наявність історичної, наукової або культурної цінності. До того ж збігатися може і суб'єктивна сторона даних злочинів. Відмежування даних злочинів слід проводити на основі характеристики їх родових та безпосередніх об'єктів, а також об'єктивної сторони. Родовим об'єктом злочину, передбаченого ст. 193 КК, є відносини власності, а безпосереднім - відносини власності та право власності на майно, що вибуло 3 фактичного володіння власника [2, с. 168]. Об'єктивна сторона даного злочину характеризується вчиненням таких діянь, як незаконне привласнення знайденого особою майна, яке має особливу історичну, наукову, художню або культурну цінність, та незаконне привласнення особою майна, яке має особливу історичну, наукову художню або культурну цінність, яке випадково опинилося у неї [3, с. 29].

Певні труднощі на практиці виникають і в розмежуванні незаконного проведення пошукових робіт на об'єкті археологічної спадщини, знищення, руйнування або пошкодження об’єктів культурної спадщини та умисного знищення або пошкодження територій, взятих під охорону держави, та об'єктів природно-заповідного фонду (ст. 252 КК). По-перше, зазначені злочини посягають на різні об'єкти кримінально-правової охорони, оскільки умисне знищення або пошкодження територій, взятих під охорону держави, та об'єктів природно-заповідного фонду є злочином проти довкілля. По-друге, різними є і предмети даних злочинів. Предметом злочину, передбаченого ст. 252 КК, є території, взяті під охорону держави, та об'єкти природно-заповідного фонду, що утворюють єдину територіальну систему і підлягають особливій охороні. До об'єктів природно-заповідного фонду належать державні заповідники, природні національні парки, заказники, пам'ятники природи, дендрологічні та зоологічні парки, заповідні урочища тощо. До таких територій відносять об'єкти природи, які являють собою велику наукову, історичну, а також лікувально-оздоровчу цінність (наприклад, Нікітський ботанічний сад у Криму, Тростянецький парк у Сумській області, Дніпровські пороги у Запорізькій області, Одеські катакомби, Володимирська гірка в Києві тощо) [2, с. 279-280]. А відповідно до ст. 1 Закону України «Про охорону культурної спадщини» від 8 червня 2000 р. до об’єктів культурної спадщини належать природні, природно-антропогенні та створені людиною об’єкти [4]. Тобто іноді об’єкти природно-заповідного фонду можуть одночасно бути і об'єктами культурної спадщини місцевого чи національного значення та бути занесеними до Державного реєстру нерухомих пам'яток України. На думку Б. М. Одайника, коли предмет посягання $€$ одночасно і об'єктом природно-заповідного фонду України, і об'єктом культурної спадщини, виникає проблема колізії норм - ст. 252 і 298 КК. Об'єктивно таке діяння реально спричинятиме шкоду і встановленому порядку охорони, відтворення i використання об'єктів природно-заповідного фонду України, і встановленому порядку поводження з пам'ятками історії, культури або археології. Науковець вважає, що відмежування в такому випадку можливе переважно за суб'єктивною стороною - як сприймає суб'єкт злочину посягання на предмет злочину: як на об'єкт природнозаповідного фонду або як на об'єкт культурної спадщини [1, с. 12]. Але така позиція є не зовсім правильною, оскільки можуть траплятися випадки, коли особа, здійснюючи посягання, розуміє, що об’єкт має історичну чи наукову цінність, але достовірно не знає, чи є він об'єктом природно-заповідного фонду України або об'єктом культурної спадщини. Можлива і ситуація, коли суб'єкт достовірно знає, що спричиняє шкоду і об'єкту природно-заповідного фонду, і об'єкту 
культурної спадщини. Тому в таких випадках діяння потрібно кваліфікувати за сукупністю норм - за ст. 252 та ст. 298 КК.

Суміжним зі ст. 298 КК складом є також наруга над могилою, іншим місцем поховання або над тілом померлого (ст. 297 КК). Зазначені склади мають спільний родовий об'єкт (суспільні відносини у сфері громадського порядку та моральності) та спільний видовий об'єкт (суспільні відносини у сфері моральності). Різняться вони між собою за безпосереднім об'єктом та предметом злочину. Безпосереднім об'єктом злочину, передбаченого ст. 297 КК, є суспільні відносини, що забезпечують загальноприйняті моральні принципи прояву поваги до пам'яті та праху покійних [2, с. 368], а предметом - могила, склеп, надмогильні споруди, огорожа, урна з прахом померлого, інше місце поховання, а також предмети, що знаходяться на могилі або в ній: тіло, останки, прах померлого, одяг на ньому, нагороди, коштовності, вінки тощо [5]. Предметом злочину, передбаченого ст. 298 КК, також може бути місце поховання та предмети, що в ньому знаходяться. Так, могили багатьох історичних постатей, письменників, художників є пам'ятками історії і культури та занесені до Державного реєстру нерухомих пам'яток України і охороняються державою. Об'єктивна сторона злочину, передбаченого ст. 297 КК, виражена в нарузі над могилою, іншим місцем поховання, над тілом, останками, прахом померлого або над урною з прахом померлого, а також у незаконному заволодінні тілом, останками, прахом померлого, урною з прахом померлого або предметами, що знаходяться на (в) могилі, в іншому місці поховання, на тілі, останках чи прахові померлого. Наруга може вчинятися шляхом осквернення могили, утворення зневажливих написів, малюнків, символів або інших зображень на пам'ятниках чи надмогильних спорудах або урні з прахом померлого. Також наруга може здійснюватися шляхом розкопування могили, пошкодження ніші в стіні, урни з прахом, осквернення труни, пошкодження пам'ятника, надгробної плити, пам'ятних написів, зображень, огорожі тощо [2, c. 368]. Таким чином, наруга може полягати й у знищенні, руйнуванні або пошкодженні об'єкта. Водночас знищення, руйнування або пошкодження не обов'язково має ознаки наруги чи осквернення, хоча і не виключає їх. Не є винятком і проведення археологічних розвідок, розкопок, інших земляних чи підводних робіт на місці поховання. Здійснення вищезазначених робіт також можна розцінювати як наругу (осквернення). Отже, об'єктивна сторона досліджуваних злочинів частково збігається. Тому якщо місце поховання, на яке відбувається посягання, є одночасно і об'єктом культурної чи археологічної спадщини, то дії винної особи слід кваліфікувати за сукупністю злочинів - за ст. 297 та 298 КК. Аналогічно вирішується така ситуація і на практиці.

Напевно, у зв'язку зі значною поширеністю вчинення зазначених злочинів у сукупності в літературі трапляються пропозиції щодо їх об'єднання в одній статті КК. Так, І. В. Ковтонюк пропонує розглянути питання про об'єднання статей 297 298 та $298^{1}$ КК в одну статтю - «Вандалізм» у такому викладі «... умисне нищення, руйнування чи псування пам'яток історії або культури, наруга над могилою, іншим місцем поховання, над трупом або урною з прахом покійного, а також викрадення предметів, що знаходяться в місці поховання або на трупі, умисне знищення, пошкодження або приховування документів Національного архівного фонду» [6, с. 606]. Але позиція зору вбачається не зовсім обгрунтованою. Як слушно зазначив О. С. Сотула, мотиви будь-якого вандалізму завжди можна тлумачити як хуліганські [7, с. 148], а виходячи із судової практики вищезазначені злочини здебільшого вчиняються з корисливих мотивів.

Наруга над державними символами (ст. 338 КК) теж є злочином, суміжним зі ст. 298 КК. Дані злочини різняться між собою за об'єктом кримінально-правової охорони, оскільки родовим об'єктом злочину, передбаченого ст. 338 КК, є суспільні відносини, що виникають між органами державної влади, органами місцевого самоврядування, об'єднаннями громадян і фізичними особами у зв'язку зі здійсненням адміністративно-розпорядчих функцій з метою захисту прав, свобод і законних інтересів фізичних і юридичних осіб [2, с. 429]. Різними є і предмети цих злочинів. Предметом злочину, передбаченого ч. 1 ст. 338 КК, $є$ Державний прапор України, Державний Герб України і Державний Гімн України, а ч. 2 ст. 338 КК - офіційно встановлений або піднятий прапор чи герб іноземної держави [2, с. 430-431]. Але об'єкт культурної спадщини місцевого чи національного значення також може містити в собі державний символ. 3 об'єктивної сторони злочин, передбачений ст. 338 КК, виражається лише у публічній нарузі над державними символами. Під наругою розуміють грубе, образливе ставлення, зле висміювання, дії, спрямовані на приниження тих цінностей, до яких інші члени суспільства ставляться з повагою (наприклад, зривання прапора чи герба, їх знищення або пошкодження, використання їх не за призначенням, учинення 
на них непристойних написів або малюнків, спотворення тексту або музики гімну, поширення його тексту зі спотворенням змісту і значення, інші дії, в яких виявляється зневажливе ставлення особи до державних символів). При цьому публічний характер дій означає, що вони можуть бути вчинені як відкрито, так і таємно, але за умови, що згодом стануть очевидними для невизначеного кола осіб [2, с. 431]. Оскільки наруга над державними символами включає в себе їх знищення або пошкодження, а знищення, руйнування або пошкодження об'єктів культурної спадщини не виключає наруги над ними, можна дійти висновку, що об'єктивна сторона зазначених злочинів частково збігається, а тому не може бути критерієм для розмежування. Таким критерієм виступає суб'єктивна сторона складів даних злочинів, а саме мета, яку ставив собі суб'єкт, вчиняючи посягання на об'єкт культурної спадщини, що містить у собі державний символ. Як слушно зазначає Б. М. Одайник, якщо суб'єкт злочину публічно руйнує чи пошкоджує (або розраховує на подальшу публічну реакцію на його дії) об'єкт культурної спадщини, який містить у собі державний символ, і має на меті через спаплюження такого символу підірвати авторитет держави, то таке діяння слід кваліфікувати за сукупністю злочинів, передбачених відповідними частинами ст. 298 і 338 КК. А у випадку, коли такий суб'єкт вчиняє подібні дії, не маючи на меті публічне осквернення такого символу (наприклад, здійснюючи незаконний демонтаж металевого зображення герба держави, який є елементом об'єкта культурної спадщини, з метою здачі його на металобрухт і отримання незаконного прибутку), то таке діяння повинно бути кваліфіковано виключно за ст. 298 КК [1, с. 13]. Так, відповідно до п. 10 Постанови Пленуму Верховного Суду України № 7 від 4 червня 2010 р. «Про практику застосування судами кримінального законодавства про повторність, сукупність і рецидив злочинів та їх правові наслідки» якщо у складі злочину передбачене діяння, окремі прояви якого у поєднанні з відповідними обставинами утворюють склад іншого злочину, то такі прояви, як правило, повинні отримувати окрему кваліфікацію [8].

\section{Висновки}

Підсумовуючи викладені у даній статті положення, слід зазначити, що до суміжних зі злочином, передбаченим ст. 298 КК, слід віднести: пошкодження релігійних споруд чи культових будинків (ст. 178 КК), незаконне утримування, осквернення або знищення релігійних святинь (ст. 179 КК), незаконне привласнення особою знайденого або чужого майна, що випадково опинилося у неї (ст. 193 КК), умисне знищення або пошкодження територій, взятих під охорону держави, та об'єктів природно-заповідного фонду (ст. 252 КК), наругу над могилою, іншим місцем поховання або над тілом померлого (ст. 297 КК) та наругу над державними символами (ст. 338 КК). Більшість із зазначених діянь відрізняються за предметом злочину, змістом суб'єктивної сторони, а також деякими особливостями об'єктивної сторони. Окрім того, іноді злочин, передбачений ст. 298 КК, слід кваліфікувати за сукупністю 3 перерахованими злочинними діяннями.

\section{Список використаних джерел:}

1. Одайник Б. М. Кримінальна відповідальність за знищення, руйнування або пошкодження пам'яток - об'єктів культурної спадщини : автореф. дис. ... канд. юрид. наук: 12.00.08. Київ, 2010. $20 \mathrm{c}$.

2. Кримінальне право України. Особлива частина : підручник / за ред. В. Я. Тація, В. І. Борисова, В. І. Тютюгіна. 5-те вид., переробл. і допов. Харків: Право, 2015. 680 c.

3. Асейкін Р. В. Відмежування злочинів, передбачених ст. 298 та $298^{1}$ КК України, від суміжних складів злочинів. Кримінальний кодекс Украйни: 10 років очікувань: матеріали міжнар. симпозіуму. (м. Львів, 23-24 вересня 2011 року). Львів : Львівський державний університет внутрішніх справ, 2011. C. $28-31$

4. Про охорону культурної спадщини : Закон України від 8 червня 2000 р. № 1805-III. Відомості Верховної Ради України. 2000. № 39. Ст. 333.

5. Про поховання та похоронну справу : Закон України від 10 липня 2003 р. № 1102-IV. Вiдомості Верховної Ради України. 2004. № 7. Ст. 47.

6. Ковтонюк I. В. Щодо поняття «вандалізму». Засади кримінального судочинства та їх реалізаиія в законотворчій $і$ правозастосовній діяльності : матеріали доп. та повідомл. наук.-практ. конф. (м. Київ, 3 квітня 2009 року). Київ : Атіка, 2009. C. $605-606$.

7. Сотула О. С. Кримінальна відповідальність за наругу над могилою та нищення, руйнування чи псування пам'яток - об'єктів культурної спадщини: проблемні аспекти. Право України. 2008. № 7. C. $147-149$.

8. Про практику застосування судами кримінального законодавства про повторність, сукупність і рецидив злочинів та їх правові наслідки : Постанова Пленуму Верховного Суду Українивід4червня2010р.№7.ВісникВерховногоСуду України. 2010. № 7. Ст. 6. 
The article is devoted to the issues of demarcation of illegal searches on the archeological heritage object, destruction, demolition or damage to the cultural heritage objects (art. 298 of the Criminal Code) from the related compositions of the crime.

The Law on Criminal Liability contains a number of crimes that can be attributed to the related ones to the crime envisaged by art. 298 of the Criminal Code of Ukraine. In this case, the ratio of related crimes should be distinguished from the competition of general and special norms. Related crimes have many common features, except one that is differentiating. Given the specific nature of the illegal conduct of archaeological exploration, excavations, other earthworks or underwater works on the archaeological heritage object, destruction, demolition or damage to the cultural heritage objects, it should be noted that most of the acts related to the crime are different from the object of the crime, the content of the subjective side, as well as some features of the objective side. Related to the crime, envisaged by art. 298 of the Criminal Code, should include: damage to religious buildings or worship houses (art. 178 of the Criminal Code), unlaw ful retention, desecration or destruction of religious shrines (art.179 of the Criminal Code), unlawful person's misappropriation of found or someone else's property accidentally found at that person (art. 193 of the Criminal Code) deliberate destruction or damage to the territories taken under the protection of the state and objects of the nature reserve fund (art. 252 of the Criminal Code), the desecration of a grave, other burial place or over the body of the deceased (art. 297 of the Criminal Code) and abuse of state symbols (art. 338 of the Criminal Code).

The relevance and importance of this article is that in practice, it often raises the question of what distinguishes the illegal conduct of prospecting at an archaeological object, destruction, demolition or damage to the cultural heritage objects from the above-mentioned related crime and in which cases the investigated crime should be qualified in the aggregate with the listed criminal offenses.

Key words: archeological exploration, archaeological excavations, desecration of grave, cultural values, religious shrines, object of the nature reserve fund. 